\title{
Subtidal sabellarid reefs in Hualien, eastern Taiwan
}

Received: 13 September 2008/ Accepted: 1 November 2008/Published online: 18 November 2008

(C) Springer-Verlag 2008

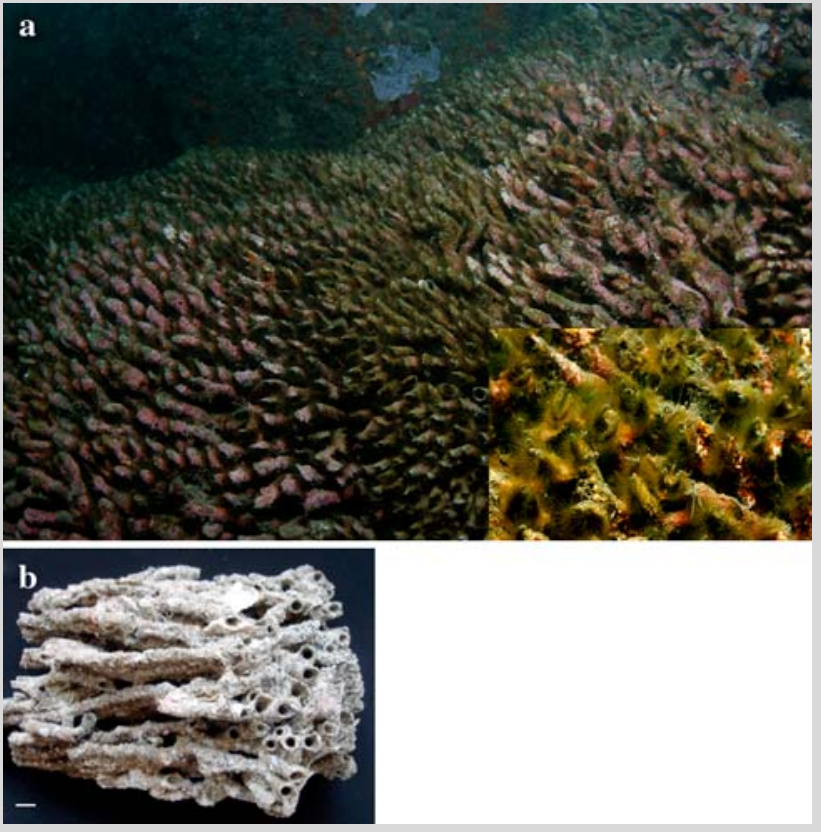

Fig. 1 a Dense aggregation of Idanthyrsus cretus on a wavebreaker and $\mathbf{b}$ a portion of worm reef, scale $=1 \mathrm{~cm}$
Sabellariid polychaetes are well known as reef builders in shallow waters throughout temperate and tropical oceans (Kirtley 1994; Pandolfi et al. 1998). They often apply mucus to sorted particles and lay tubes as building blocks of reef structure (Kirtley 1994). They typically occur in dense aggregations and form mounds or reef-like structures in intertidal or subtidal areas off coasts of America and the Mediterranean Sea. In May 2008, we discovered well-developed sabellariid reefs on subtidal wavebreakers that extend for about $1 \mathrm{~km}$ near Hualien Port $\left(23^{\circ} 58.155 \mathrm{~N}, 121^{\circ} 36.905 \mathrm{E}\right)$ in eastern Taiwan. Densely aggregated tubes of $I$ danthyrsus cretus Chamberlin, 1919 piled up as reef masses and extend from 1 to $7 \mathrm{~m}$ in depth near the sandy bottom (Fig. 1). The density reaches 5,400 worm tubes $/ \mathrm{m}^{2}$, with a gradual decrease as water depth increases. The average thickness of the worm reef is $10.1 \pm 10.4 \mathrm{~cm}$ (mean \pm SD) and the maximum is about $50 \mathrm{~cm}$ at depth between 3 and $5 \mathrm{~m}$. Based on the installation date of wavebreakers in 1996-2003, the estimated growth rate of the worm reefs was about $4.2-10.0 \mathrm{~cm} /$ year, which is higher than the accretion rates of most coral reefs.

The sabellariid reefs provide substrata for a

diverse community of epifauna and infauna, and their ecological roles are comparable to those of the tropical coral reefs. In addition, they form consolidated structures that offer protective cover to wavebreakers, which further help stabilizing the substrate. This is the first observation of $I$. cretus as a primary frame-builder forming subtidal reefs in the West Pacific, since it has not been recorded as fossils nor in the extant forms in this area (Pandolfi et al. 1998). The occurrence of $I$. cretus reefs along the Hualien coast is possibly due to a concurrence of various local environmental conditions, where there is an abundant supply of terrestrial organic particles and sand-size sediment, vigorous wave action, and strong currents. These unusual sabellarid reefs invite further ecological and biological studies.

Acknowledgments We thank the 9th River Basin Management Bureau, Water Resources Agency, Ministry of Economic Affairs, Executive Yuan, ROC, for their support of this survey. We are also grateful to Dr. YuHuai Wang for logistic support.

\section{References}

Kirtley DW (1994) A review and taxonomic revision of the family Sabellariidae Johnston 1865 (Annelida; Polychaeta). Sabecon Press, Vero Beach, FL

Pandolfi JM, Robertson DR, Kirtley DW (1998) Roles of worms in reef-building. Coral Reefs 17:120

C. Chen · C.-F. Dai $(\bowtie)$

Institute of Oceanography, National Taiwan University, Taipei 106, Taiwan, ROC e-mail: corallab@ntu.edu.tw

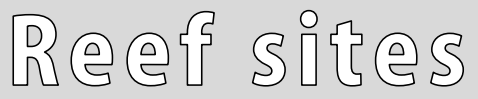

Coral Reefs (2009) 28:275

DOI $10.1007 / \mathrm{s} 00338-008-0448-6$ 